ISSN 1392-3196 / e-ISSN 2335-8947

Zemdirbyste-Agriculture, vol. 101, No. 4 (2014), p. 403-410

DOI 10.13080/z-a.2014.101.051

\title{
The impact of lime and nitrogen fertilization on cocksfoot and reed canary grass productivity in Albeluvisol and energy evaluation of their cultivation technology
}

\author{
Gintaras ŠIAUDINIS ${ }^{1}$, Danute KARČAUSKIENE ${ }^{1}$, Alvyra ŠLEPETIENE் ${ }^{2}$ \\ ${ }^{1}$ Vèžaičiai Branch, Lithuanian Research Centre for Agriculture and Forestry \\ Gargždų 29, Vèžaičiai, Klaipėda distr., Lithuania \\ E-mail: gintaras@vezaiciai.lzi.lt \\ ${ }^{2}$ Institute of Agriculture, Lithuanian Research Centre for Agriculture and Forestry \\ Instituto 1, Akademija, Kèdainiai distr., Lithuania
}

\begin{abstract}
Research on two perennial Poaceae species - cocksfoot (Dactylis glomerata L.) and reed canary grass (Phalaris arundinacea L.) - was aimed to investigate the effect of liming and nitrogen fertilization on biomass productivity and to carry out energy analysis of the growing technology. The soil of the experimental site is acid moraine loam ( $\mathrm{pH}$ 4.25-4.85) Eutri-Hypostagnic Albeluvisol (ABj-w-eu). The experiments were composed of three levels of liming (not limed, limed with 3.0 and $6.0 \mathrm{t} \mathrm{ha}^{-1}$ of $\left.\mathrm{CaCO}_{3}\right)$ and three levels of nitrogen $(\mathrm{N})$ fertilization $(0,60$ and $\left.120 \mathrm{~kg} \mathrm{ha}^{-1} \mathrm{~N}\right)$.

According to the results averaged over three years of investigations, the highest productivity was obtained in 2011 , when the average cocksfoot dry mass yield amounted to $7215 \mathrm{~kg} \mathrm{ha}^{-1}$, and reed canary grass - to $10833 \mathrm{~kg}$ $\mathrm{ha}^{-1}$ (including $1^{\text {st }}$ and $2^{\text {nd }}$ cuts). The application of $6.0 \mathrm{t} \mathrm{ha}^{-1} \mathrm{CaCO}_{3}$ lime rate positively affected cocksfoot dry mass increment, although had no significant influence on reed canary grass dry mass yield. Nitrogen fertilization had the highest effect on the productivity of both grasses. Compared with the control treatment $\left(0 \mathrm{~kg} \mathrm{ha}^{-1} \mathrm{~N}\right)$, the application of $120 \mathrm{~kg} \mathrm{ha}^{-1} \mathrm{~N}$ rate increased cocksfoot dry mass by $220 \%$ and reed canary grass by $243 \%$.

The energy evaluation of growing technology showed that the total energy input for grass cultivation (direct and indirect input, machinery energy consumption and human labour input) amounted to 8.91-26.02 $\mathrm{GJ}^{-1} \mathrm{ha}^{-1}$, of which liming material and mineral fertilizers accounted for 2.45-19.39 $\mathrm{GJ}^{-1} \mathrm{ha}^{-1}$. Cocksfoot accumulated 59-165 GJ ha' and reed canary grass $84-228 \mathrm{GJ} \mathrm{ha}^{-1}$ of biomass energy on average per season. As a result, the highest energy use efficiency (energy output/input ratio), which was positively influenced by $120 \mathrm{~kg} \mathrm{ha}^{-1} \mathrm{~N}$ fertilization, was achieved when growing reed canary grass.
\end{abstract}

Key words: Dactylis glomerata, energy evaluation of growing technology, lime, nitrogen, Phalaris arundinacea.

\section{Introduction}

The recent increases in the price of oil have reminded us of our strong reliance on fossil fuels world petroleum resources (Wrobel et al., 2009). So far, renewable sources, in particular energy crops have made up relatively small share in energy production; however, their proportion has substantially increased during the last few decades. With increasing demand for bioenergy production, the greatest interest has been expressed in perennial plant species, which enable production of high biomass amounts, which, in turn, could be utilized for energy purposes (McKendry, 2002; Wrobel et al., 2009). In other moderate climate European countries as well as in Lithuania, tall perennial grasses have been displaying beneficial attributes as energy crops and a growing interest since the last two decades of the $20^{\text {th }}$ century. The most promising are tall perennial grasses, whose feeding value is not high; however, their high biomass productivity can be maintained stable for 8-10 years.
The most promising regions for energy crops cultivation could be those with less suitable conditions for traditional agriculture. Western Lithuania's region has a wide range of soils, though naturally acid Albeluvisol $(A B)$ and Fluvisol $(F L)$ are prevalent. Liming is an effective means to control soil acidity (Mažvila, 2010). However, the wide scale of liming was suspended over two decades ago, thus the soils are gradually returning to their initial acidity level. Compared with other terrains of the country, the acidification process is hastened due to higher amounts of precipitation, which accelerates the leaching of mineral nutrients (Mažvila, 2010). Regarding this, the agricultural sector is often unprofitable. One of the alternative solutions is cultivation of energy crops and their subsequent conversion into biofuel. The use of biomass of perennial grasses would be a promising business in the near future. Today, the most promising are those grass species, which are not demanding in terms of growing conditions, are 
resistant to wintering, drought, their biomass is well suited for solid biofuel and biogas production (Lewandowski et al., 2003; Šateikis, 2006; Tilvikienè et al., 2012). Such species are cocksfoot and reed canary grass.

Reed canary grass (Phalaris arundinacea L.) is one of the most promising bio-energy crops in European regions with temperate and boreal climate. However, its productivity is highly uneven and depends on many factors (Lewandowski et al., 2003; Heinsoo et al., 2011; Tilvikiene et al., 2012). However, there is a lack of data on the response of reed canary grass to liming (or different soil $\mathrm{pH}$ ). Pot and field experiments conducted in Canada and Estonia show that reed canary grass cultivated in highly acid $\left(\mathrm{pH}_{\mathrm{KCl}} 3.0-4.0\right)$ organic soil produces substantially lower biomass yield (Levesque, Mathur, 1983; Heinsoo et al., 2011). Research done in different localities of Czech Republic suggests higher reed canary grass productivity in less acid soils; however, its productivity is also shown to depend on other soil and weather factors (Strašil, 2012). Many Lithuanian and foreign authors note the positive impact of $\mathrm{N}$ on reed canary grass productivity. Altogether, nitrogen efficiency is uneven and depends on various agrometeorological factors (Kryževičienė, 2006; Saijonkari-Pahkala, 2001; Strašil, 2012; Tilvikienè et al., 2012).

As energy crop, cocksfoot (Dactylis glomerata L.) has received less attention, although recently it has become a common forage grass. It has been reported that new cocksfoot lines are characterized by high biomass productivity (Tarakanovas, Chomiak, 2008; Tilvikienè et al., 2012). The sparse experiments with liming reveal that when growing cocksfoot under severe acid soil conditions in pure sward as well as in mixture with other crops, its productivity is increasing when the lime is applied (Junquan et al., 2007; Poozesh et al., 2010). The effects of different nitrogen rates on cocksfoot biomass and energy productivity are presented by Lithuanian and foreign authors (Mills et al., 2009; Tilvikienè et al., 2012).

Since our investigations were carried out in the region with soils of different soil acidity, the trials encompassed different soil $\mathrm{pH}$ levels. There is a lack of data on how soil acidity (different soil $\mathrm{pH}$ levels) influences cocksfoot and reed canary grass productivity. So far, there has been no data concerning the interaction of liming and nitrogen fertilization and their effect on cocksfoot and reed canary grass productivity. Besides, we aimed to evaluate the grass growing technology from the energy point of view. The same grass growing technology and equipment could be applied for cultivation of grasses for forage as well as for energy purposes (Grass forage production, 2001). At the same time, the energy balance of respective technologies is highly uneven and depends on many factors, including fertilization rate, weather conditions and others (Jasinskas et al., 2008; Shahin et al., 2008).

In these experiments, we attempted to evaluate the effect of soil liming and nitrogen fertilization on cocksfoot and reed canary grass dry mass yield $\left(1^{\text {st }}\right.$ and $2^{\text {nd }}$ cuts) under different conditions of experimental years on Western Lithuania's Albeluvisol and analyse their growing technology.

\section{Materials and methods}

The investigations with perennial energy grasses - cocksfoot and reed canary grass were carried out in Vèžaičiai Branch of the Lithuanian Research Centre for Agriculture and Forestry $\left(55^{\circ} 43^{\prime} \mathrm{N}, 21^{\circ} 27^{\prime}\right.$ E) during 2009-2012. The soil of the experimental site is naturally acid moraine loam (Eutri-Hypostagnic Albeluvisol, ABj$w$-eu) with the following characteristics: $\mathrm{pH}_{\mathrm{KCl}}-4.25-$ 4.85 , mobile $\mathrm{P}_{2} \mathrm{O}_{5}-35-120 \mathrm{mg} \mathrm{kg}^{-1}$, mobile $\mathrm{K}_{2} \mathrm{O}-140$ $209 \mathrm{mg} \mathrm{kg}^{-1}$, hydrolytic acidity $-21.9-62.1$ mequiv $\mathrm{kg}^{-1}$, mobile $\mathrm{Al}-10.7-50.9 \mathrm{mg} \mathrm{kg}^{-1}$. The field experiments were laid out in a two-factor design. Factor A-liming: not limed, limed by 3.0 and $6.0 \mathrm{tha}^{-1} \mathrm{CaCO}_{3}$ rates. Thus, the experimental site was divided into three strips differing in soil $\mathrm{pH}$ level. Factor $\mathrm{B}$ - nitrogen $(\mathrm{N})$ application levels: 0,60 and $120 \mathrm{~kg} \mathrm{ha}^{-1}$. All nitrogen treatments with three replications were randomly allocated in all three $\mathrm{pH}$ strips.

To establish the different soil $\mathrm{pH}$ levels, two strips of the experimental site were limed. Liming was performed (except for the first $\mathrm{pH}$ strip) using Opokos lime material in 2008, one year before trial establishment. Nitrogen at a rate of $60 \mathrm{~kg} \mathrm{ha}^{-1}$ was spread in April just at the beginning of vegetation. An additional $60 \mathrm{~kg} \mathrm{ha}^{-1}$ $\mathrm{N}$ rate (for the $3^{\text {rd }}$ treatment) was applied in July, just after the $1^{\text {st }}$ cut of grass. In the experiments, ammonium nitrate was applied as nitrogen fertilizer. Phosphorus and potassium fertilizers were spread each year prior to the beginning of vegetation. The rates of phosphorus and potassium fertilizers for all the experimental plots were the same $60 \mathrm{~kg} \mathrm{ha}^{-1} \mathrm{P}_{2} \mathrm{O}_{5}$ and $60 \mathrm{~kg} \mathrm{ha}^{-1} \mathrm{~K}_{2} \mathrm{O}$. Phosphorus fertilization was applied as single superphosphate and potassium as potassium chloride. Prior to the establishment of trials in order to destroy annual and perennial weeds, the experimental site was sprayed with the herbicide Roundup (a.i. glyphosat $360 \mathrm{~g} \mathrm{l}^{-1}$ ). At 2-3 leaf stage, to destroy dicotyledonous weed seedlings, grass swards were sprayed with the herbicide Betanal (a.i. phenmedipham $157 \mathrm{~g} \mathrm{l}^{-1}$ ).

Both perennial grasses - cocksfoot (Dactylis glomerata L.) cv. 'Amba' and reed canary grass (Phalaris arundinacea L.) cv. 'Chieftain' were sown on $14^{\text {th }}$ July, 2009 at a rate of $15 \mathrm{~kg} \mathrm{ha}^{-1}$ of viable seeds. The harvested area of each grass plot was $14 \mathrm{~m}^{2}$. The first cut was taken at full maturity stage on $28^{\text {th }}$ of June 2010, $28^{\text {th }}$ of June 2011 and $3^{\text {rd }}$ of July in 2012. The second cut (aftermath) was taken on $30^{\text {th }}$ of September 2010 , on $24^{\text {th }}$ of September in 2011 and on $26^{\text {th }}$ of September in 2012. Energy equivalents express the input of energy associated with the manufacture of production means of primary energy input (Hulsbergen et al., 2001). By calculating indirect energy input, the following energy equivalents $\left(\mathrm{MJ} \mathrm{kg}^{-1}\right)$ of mineral fertilizers were used for calculation: for ammonium nitrate -27.4 , for single superphosphate -6.4 , for potassium chloride -5.3 , for lime material 1.79 (Hulsbergen et al., 2001). Energy equivalents for herbicides was 288 (Green, 1987) and for grass seeds - 7. The estimated calorific value for cocksfoot was $17.60 \mathrm{MJ} \mathrm{kg}^{-1}$ and reed canary grass $-17.47 \mathrm{MJ} \mathrm{kg}^{-1}$. 
Biomass calorific value was measured by IKA C 5000 control calorimeter equipment at Klaipeda University's Maritime Institute Laboratory. The accumulated energy (or energy output GJ ha ${ }^{-1}$ ) from 1 ha in grass swards was calculated by multiplying dry mass (DM) yield by calorific value. For the evaluation of growing and harvesting technology of the perennial grasses, the following energy inputs were included: a) direct energy input, b) indirect energy input, c) energy input of machinery and d) human labour input (Grass forage production, 2001; Jasinskas, 2003). Diesel consumption was recalculated into MJ coefficient $\mathrm{k}=42.7 \mathrm{MJ} \mathrm{kg}^{-1}$ (Grass forage production, 2001). Energy utilization efficiency (EUE) was calculated by equation: $E U E$ = energy output/input ratio) (Shahin et al., 2008).

A three-way analysis of variance was performed on the data of cultivation year, soil $\mathrm{pH}$ and nitrogen rate, and their mutual interactions using analysis of variance (ANOVA) to determine significance at $95 \%$ probability level $\left(\mathrm{LSD}_{05}\right)$ (Tarakanovas, Raudonius, 2003).

In 2010, the sum of precipitation was $620 \mathrm{~mm}$. There were two warm and dry periods - in the middle of July and middle of August. Humid and cool weather prevailed at the end of July and the period from late August to the end of vegetation. The sum of active temperatures was $2246^{\circ} \mathrm{C}$. In 2011 , the distribution of precipitation was relatively uniform throughout the growing season $(540 \mathrm{~mm})$. The weather conditions for plant growth and development were more favourable than in the other experimental years. The sum of active temperatures totalled $2400^{\circ} \mathrm{C}$. In the first half of 2012 vegetation, moderately warm weather prevailed. During the intensive growing stage of grass, there was a lack of humidity in the upper soil surface. The amount of precipitation gradually increased in the second half of vegetation. The amount of precipitation totalled $394 \mathrm{~mm}$, and the sum of active temperatures was $2182^{\circ} \mathrm{C}$.

\section{Results and discussion}

Cocksfoot. The averaged results of cocksfoot above-ground DM yield are presented in Figure 1. According to the averaged data of the three experimental years, the most favourable conditions (water and temperature regimes) for DM accumulation were in 2011. The DM yield (of $1^{\text {st }}$ and $2^{\text {nd }}$ cuts) values were significantly higher compared with the other growing seasons. Thus in 2011, the average DM yield amounted to $7215 \mathrm{~kg} \mathrm{ha}^{-1}$. Yet in 2012, total DM productivity decreased sharply and amounted to $5165 \mathrm{~kg} \mathrm{ha}^{-1}$, on average $(28.41 \%$ lower than in 2011). The low total productivity was caused by low DM amount in aftermath grass, especially in the treatments, which did not receive $\mathrm{N}$ fertilization for the third year in succession from the establishment of the experiment. The share of $1^{\text {st }}$ cut DM yield increased from $55.12 \%$ (in 2010) to $73.15 \%$ (in 2012).

The peculiarities of annual variation in dry mass increments agree with the results of other experiments done at Lithuanian Research Centre for Agriculture and Forestry which suggest that the DM yield of $1^{\text {st }}$ and $2^{\text {nd }}$ harvest seasons of different cocksfoot cultivars amounted to $7640-9450 \mathrm{~kg} \mathrm{ha}^{-1}$; meanwhile DM yield sharply decreased (down to $37-50 \%$ ) during $3^{\text {rd }}$ and $4^{\text {th }}$ harvest years (Tarakanovas, Chomiak, 2008). Besides, the lack of moisture in June-July notably reduced the aftermath DM increment. The lesser lime rate $\left(3.0 \mathrm{t} \mathrm{ha}^{-1}\right)$ did not affect DM increase. However, the application of 6.0 $\mathrm{t} \mathrm{ha}^{-1}$ rate positively influenced the average cocksfoot productivity of $1^{\text {st }}$ and $2^{\text {nd }}$ cuts (4449 and $2849 \mathrm{~kg} \mathrm{ha}^{-1}$, respectively) and thus the total annual DM productivity up to $7298 \mathrm{~kg} \mathrm{ha}^{-1}$. Compared with the control treatment, the $\mathrm{N}$ rate of $60 \mathrm{~kg} \mathrm{ha}^{-1}$ increased DM yield by $40.18 \%$ (or by $2275 \mathrm{~kg} \mathrm{ha}^{-1}$ ), on average. The highest $120 \mathrm{~kg} \mathrm{ha}^{-1}$ $\mathrm{N}$ rate increased DM yield of $1^{\text {st }}$ cut from 2195 to 4558 $\mathrm{kg} \mathrm{ha}^{-1}$ (or by 208\%) and $2^{\text {nd }}$ cut from 1608 to $3800 \mathrm{~kg}$ ha $^{-1}$ (by $236 \%$ ). Overall, compared with $\mathrm{N}$ non-fertilized plots the total annual yield increased by $220 \%$ (up to $8358 \mathrm{~kg} \mathrm{ha}^{-1}$ ).

Statistically significant interaction between nitrogen and liming application was noticed in several cases; yet, it cannot be identified as consistent. With reference to the data of other authors, soil liming is a positive factor for cocksfoot productivity. When soil acidity is very high $\left(\mathrm{pH}_{\mathrm{KCl}} 3.9\right)$, liming causes the increase of DM yield by $2370 \mathrm{~kg} \mathrm{ha}^{-1}$, on average (given the average cocksfoot DM productivity of $6290 \mathrm{~kg} \mathrm{ha}^{-1}$ per year) (Poozesh et al., 2010). Although cocksfoot is

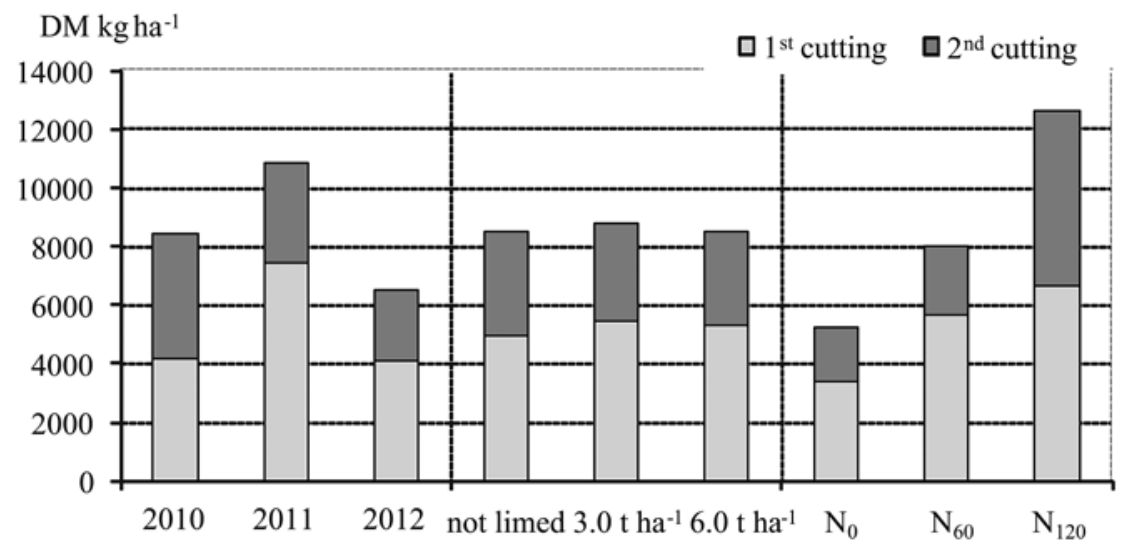

Figure 1. The influence of cultivation year, liming and nitrogen $(\mathrm{N})$ fertilization on mean values of cocksfoot dry mass (DM) yield in 2010-2012 
more tolerant of relative high levels of exchangeable aluminium (Al) than many other grass species, the application of $1500 \mathrm{~kg} \mathrm{ha}^{-1} \mathrm{yr}^{-1}$ of burnt lime in moderately and strongly acidic soils caused the increase of cocksfoot DM productivity by $2084 \mathrm{~kg} \mathrm{ha}^{-1}$, on average per three years (Junquan et al., 2007).

Reed canary grass. Figure 2 shows the average results of reed canary grass DM yield. The most productive was 2011, when reed canary grass sward accumulated up to $10833 \mathrm{~kg} \mathrm{ha}^{-1}\left(7432 \mathrm{~kg} \mathrm{ha}^{-1}\right.$ of $1^{\text {st }}$ cut and $3401 \mathrm{~kg} \mathrm{ha}^{-1}$ of $2^{\text {nd }}$ cut) DM. Contrarily, DM yield sharply decreased (both $1^{\text {st }}$ and $2^{\text {nd }}$ cuts) in the next 2012 season, and amounted to just $6505 \mathrm{~kg} \mathrm{ha}^{-1}$ (or $39.95 \%$ less than in 2011). In the total DM yield, the share of $2^{\text {nd }}$ cut reed canary grass sward evidently decreased from $51.27 \%$ (in 2010) to $37.05 \%$ (in 2012). Like in the case of cocksfoot, reed canary grass productivity and its seasonal fluctuations depending on growing conditions are reported by other authors (Strašil, 2012). The effect of liming was less obvious. In all experimental years, liming $\left(3.0 \mathrm{t} \mathrm{ha}^{-1}\right.$ $\mathrm{CaCO}_{3}$ ) positively influenced DM productivity of $1^{\text {st }}$ cut. Compared with not limed plots, DM yield increased by
$8.21 \%$. However, no liming rate had significant influence on the $2^{\text {nd }}$ cut of grass as well as total annual DM yield. Moreover, the interaction of liming with $\mathrm{N}$ fertilization was statistically insufficient in all the cases. As it was mentioned before, the positive effect of liming on reed canary grass productivity was found under highly acid soil conditions ( $\mathrm{pH}<4.0$ ), only. Our experiments were carried out in less acid soil and the results of the studies corroborate the statement that reed canary grass as a crop is tolerant to a wide soil $\mathrm{pH}$ range from 4.9 to 8.2 (Carlson et al., 1996). Thus, liming is not an efficient means for improving reed canary grass productivity. Essentially, the sharp increase in DM productivity was determined by $\mathrm{N}$ fertilization. The highest effect was of $120 \mathrm{~kg} \mathrm{ha}^{-1}$ application, which distinctly increased the yield of $1^{\text {st }}$ and $2^{\text {nd }}$ cuts as well as total DM yield to $12619 \mathrm{~kg} \mathrm{ha}^{-1}$ (or $243 \%$ higher compared with $0 \mathrm{~kg} \mathrm{ha}^{-1} \mathrm{~N}$ ). All the differences were above $99 \%$ probability level. Nitrogen application evidently increased the share of grass of the $2^{\text {nd }}$ cut (aftermath) from $34.65 \%\left(0 \mathrm{~kg} \mathrm{ha}^{-1} \mathrm{~N}\right)$ to $47.66 \%$ $\left(120 \mathrm{~kg} \mathrm{ha}^{-1} \mathrm{~N}\right)$.

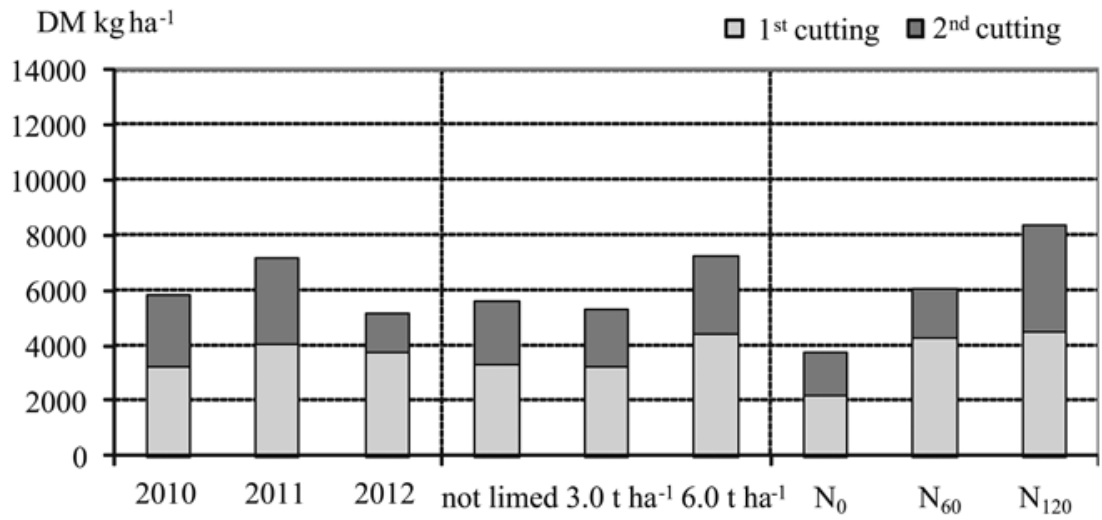

Figure 2. The influence of cultivation year, liming and nitrogen $(\mathrm{N})$ fertilization on mean values of reed canary grass dry mass (DM) yield in 2010-2012

Several other experiments with reed canary grass conducted in Central Lithuania (under $\mathrm{pH}$ 5.5-7.0) revealed that by application of nitrogen fertilization twice per vegetation $\left(60+60 \mathrm{~kg} \mathrm{ha}^{-1}\right)$ per two cuts and depending on growing year conditions, DM yield reached 6400-9300 kg ha ${ }^{-1}$ (Kryževičienè et al., 2008). However, by performing grass sward harvesting only once per season, depending on the time of cutting and under varying agrometeorological conditions, the application of $120 \mathrm{~kg} \mathrm{ha}^{-1} \mathrm{~N}$ rate caused the variation of reed canary grass DM yield from 5580 to $7490 \mathrm{~kg} \mathrm{ha}^{-1}$ (Kryževičienè et al., 2005; Jasinskas et al., 2008).

Estonian researches emphasize that depending on soil type, reed canary grass yield reaches $12700 \mathrm{~kg}$ $\mathrm{ha}^{-1} \mathrm{DM}$ on different types of mineral soils and $7200 \mathrm{~kg}$ $\mathrm{ha}^{-1}$ on organic soils (Heinsoo et al., 2011). Other authors suggest that autumn harvest of perennial grasses might be substituted by spring harvesting. A $23 \%$ loss of biomass over the winter period is compensated for by the reduction in moisture as well as potassium, chlorine, nitrogen and sulphur content. This, in turn, improves biomass energy parameters (Strašil, 2012). The above presented data evidently reveals that the variations in both perennial grasses productivity, i.e. the effects of year, liming and $\mathrm{N}$ fertilization were similar.

Nevertheless, in all three experimental years, reed canary grass productivity was $7-45 \%$ higher than that of cocksfoot. It was noticed by other researches that beside $\mathrm{N}$ rate, the DM productivity of both grasses varied depending on grass cutting frequency as well as growth stage. Thus, the trials done in Central Lithuania revealed that growing the same cocksfoot and reed canary grass varieties ('Amba' and 'Chieftain', respectively) on an Endocalcari-Endohypogleyic Cambisol (CMg-p-w-can) (under $\mathrm{pH}$ 5.5-7.0), the average reed canary grass DM yield (with $90-180 \mathrm{~kg} \mathrm{ha}^{-1} \mathrm{~N}$ application) varied from 8270 to $9410 \mathrm{~kg} \mathrm{ha}^{-1}$; meanwhile cocksfoot DM yield was higher - 1039-1147 kg ha-1 (Tilvikienè et al., 2012).

The results of the experiment show that grass swards in the plots, which had been annually applied with $\mathrm{N}$, were luxuriant after three years of vegetation. The grass swards in the plots, which received no $\mathrm{N}$ 
supply, began gradually thinning. Due to reduction of soil mineral nitrogen amount and the subsequent decreasing of competitive power of both investigated species (in particularly cocksfoot sward), the significant number of other grass forbs began predominating. These observations agree with the data of other researchers (Strašil, 2012).

Energy evaluation of growing technology. The direct energy expenses and their distribution are presented in Table 1. When calculating direct expenses for growing, we included working operations used in the experiments. Autumn soil ploughing, soil cultivation, distribution of lime and mineral fertilizers (potassium and phosphorus), sowing and harrowing, plant protection against weeds were done during the sowing year in 2009. In 2010-2012, except distribution of nitrogen fertilizers, all other working operations were related to grass harvesting and transportation to storage, i.e. grass cutting, grass turning, grass raking into windrows, grass collecting and pressing, round bale loading and transportation to loading place (up to $5 \mathrm{~km}$ distance) and loading into storage place. Direct energy input totalled $37023822 \mathrm{MJ} \mathrm{ha}^{-1}$. The highest proportion fell to grass harvesting expenses (6-12 operations), which comprised $2828 \mathrm{MJ} \mathrm{ha}^{-1}$ (or $74 \%$ to $76.4 \%$ of total direct inputs).

Table 1. The evaluation of direct energy input, machinery energy and human labour input for particular operation of cocksfoot and reed canary grass cultivation technology

\begin{tabular}{|c|c|c|c|}
\hline Operations & $\begin{array}{l}\text { Direct energy input } \\
\mathrm{MJ} \mathrm{ha}^{-1}\end{array}$ & $\begin{array}{l}\text { Machinery for particular operation } \\
\qquad \mathrm{MJ} \mathrm{ha}^{-1}\end{array}$ & $\begin{array}{c}\text { Energy input } \\
\text { of human labour } \\
\mathrm{MJ} \mathrm{ha}^{-1}\end{array}$ \\
\hline 1.Soil ploughing & 576 & $77.1+27.8$ & 1.8 \\
\hline 2. Soil cultivation & 217.8 & $77.1+24.1$ & 0.65 \\
\hline 3. Plant protection against weeds & 42.7 & $10.62+13.12 \times 2$ & 0.64 \\
\hline $\begin{array}{l}\text { 4. Distribution of fertilizers } \\
*, * *, * * *\end{array}$ & $\begin{array}{c}59.8^{*} \\
(137)^{* *} \\
(179.4)^{* * *}\end{array}$ & $\begin{array}{c}10.62+11.25 * \\
(10.62+11.25) \times 2 * * \\
(10.62+11.25) \times 3 * * *\end{array}$ & $\begin{array}{c}0.38^{*} \\
(0.76)^{* *} \\
(1.14)^{* * *}\end{array}$ \\
\hline 5. Sowing and harrowing & 20.0 & $77.1+149+20.0$ & 1.04 \\
\hline 6. Grass cutting & 196.4 & $77.1+24.0$ & 0.9 \\
\hline 7. Grass turning & 213.5 & $77.1+36.6$ & 0.2 \\
\hline 8. Grass raking into windrows & 106.7 & $77.1+36.6$ & 0.39 \\
\hline 9. Grass collecting and pressing & 234.8 & $77.1+165.7$ & 1.8 \\
\hline 10. Round bale loading & 341.6 & $77.1+38.8$ & 2.68 \\
\hline 11. Transportation & 1393.7 & $77.1+279.7$ & 8.4 \\
\hline 12. Loading into storage place & 341.6 & $77.1+38.8$ & 2.68 \\
\hline Total & $3702-3779-3822$ & $1681-1703-1725$ & $20.53-21.94-22.32$ \\
\hline
\end{tabular}

The share of energy input of human labour makes up 20.53-22.32 $\mathrm{MJ} \mathrm{ha}^{-1}$. In the above-proposed technological version, each technological process is maximally mechanized with the minimal input of human labour (Jasinskas et al., 2008). When evaluating cocksfoot and reed canary grass growing technology, indirect energy expenses were calculated as well (for plant protection, distribution of fertilizers, sowing and harrowing operations). Indirect inputs involve the share of energy bound in seeds, pesticides, lime material and mineral fertilizers. The same grass growing and harvesting technology is suitable for forage production as well as for biofuel purposes. In both cases, perennial grasses have to be cut, dried to $17-20 \%$ moisture content, pressed into round bales, transported into storage and kept until consumption or burning in special furnaces (Jasinskas, 2003). Depending on liming and $\mathrm{N}$ fertilization level, the share of indirect inputs totalled 3.51-20.45 MJ ha-1 (Table 2 ). Out of them, lime material and mineral fertilizers constituted the major portion of total energy expenses. Total energy input ranged from 8.91 to $26.02 \mathrm{GJ} \mathrm{ha}^{-1}$. The application of only phosphorus and potassium fertilizers (in control treatment) constituted $2.45 \mathrm{GJ} \mathrm{ha}^{-1}$ (33.98\%) of total energy inputs (direct and indirect). However, the application of the highest lime and $\mathrm{N}$ rates increased the share of lime and fertilizers up to $19.39 \mathrm{GJ}^{-1}$ $(79.89 \%)$ of total energy inputs. The large energy share of mineral fertilizers is explainable by the fact that the manufacturing of synthetic fertilizers also requires large energy consumption. However, according to Hulsbergen et al. (2001) survey, the energy requirements to produce mineral fertilizers (particularly nitrogen) are gradually declining.

Application of $120 \mathrm{~kg} \mathrm{ha}^{-1} \mathrm{~N}$ rate obviously increased the amount of accumulated energy in cocksfoot biomass from 51.3 to $165 \mathrm{GJ}^{-1}$ (by $322 \%$ ), and reed canary grass from 84.33 to $228 \mathrm{GJ} \mathrm{ha}^{-1}$ (by 270\%). Due to higher biomass productivity, reed canary grass accumulated substantially higher energy amount compared with cocksfoot grass. In contrast, lime fertilizers marginally influenced the energy accumulation in both crops' biomass. Energy use efficiency (EUE) of reed canary grass ranged from 6.32 to 12.80 and in all cases was higher than that of cocksfoot (4.71-8.22). Commonly, the application of lime material caused the decrease in EUE values. The opposite was the effect of $120 \mathrm{~kg} \mathrm{ha}^{-1} \mathrm{~N}$ rate. 
Table 2. Energy evaluation of cocksfoot and reed canary grass growing technology, 2010-2012

\begin{tabular}{|c|c|c|c|c|c|c|c|}
\hline \multirow{2}{*}{ Treatments } & $\begin{array}{l}\text { Indirect } \\
\text { energy } \\
\text { innut }\end{array}$ & $\begin{array}{l}\text { Total } \\
\text { energy } \\
\text { input }\end{array}$ & $\begin{array}{c}\text { Share of } \\
\text { lime and mineral } \\
\text { fertilizers }\end{array}$ & \multicolumn{2}{|c|}{$\begin{array}{l}\text { Total energy output } \\
\text { GJ ha-1 }\end{array}$} & \multicolumn{2}{|c|}{ Energy use efficiency } \\
\hline & \multicolumn{3}{|c|}{ GJ ha ${ }^{-1}$} & $\begin{array}{l}\text { cocks- } \\
\text { foot }\end{array}$ & $\begin{array}{l}\text { reed canary } \\
\text { grass }\end{array}$ & $\begin{array}{l}\text { cocks- } \\
\text { foot }\end{array}$ & $\begin{array}{l}\text { reed canary } \\
\text { grass }\end{array}$ \\
\hline Not limed $+0 \mathrm{~kg} \mathrm{ha}^{-1} \mathrm{~N}$ & 3.51 & 7.21 & 2.45 & 59.1 & 84.3 & 8.20 & 11.69 \\
\hline Not limed $+120 \mathrm{~kg} \mathrm{ha}^{-1} \mathrm{~N}$ & 13.25 & 17.03 & 12.19 & 140 & 218 & 8.22 & 12.80 \\
\hline $3.0 \mathrm{tha}^{-1} \mathrm{CaCO}_{3}+0 \mathrm{~kg} \mathrm{ha}^{-1} \mathrm{~N}$ & 7.11 & 10.89 & 6.05 & 51.3 & 96.6 & 4.71 & 8.87 \\
\hline $3.0 \mathrm{tha}^{-1} \mathrm{CaCO}_{3}+120 \mathrm{~kg} \mathrm{ha}^{-1} \mathrm{~N}$ & 16.85 & 20.67 & 15.7 & 140 & 215 & 6.77 & 10.40 \\
\hline $6.0 \mathrm{t} \mathrm{ha}^{-1} \mathrm{CaCO}_{3}+0 \mathrm{~kg} \mathrm{ha}^{-1} \mathrm{~N}$ & 10.71 & 14.49 & 9.65 & 91.6 & 91.6 & 6.32 & 6.32 \\
\hline $6.0 \mathrm{tha}^{-1} \mathrm{CaCO}_{3}+120 \mathrm{~kg} \mathrm{ha}^{-1} \mathrm{~N}$ & 20.45 & 24.27 & 19.39 & 165 & 228 & 6.80 & 9.39 \\
\hline
\end{tabular}

These results agree with those of similar investigations. Our results confirm the results of other investigations that reed canary grass is advantageous for low establishing inputs, minimal requirements for pesticides and other direct inputs (Strašil, 2012). Estonian researches have noted that by increasing reed canary grass growing energy expenses from 6 to $31 \mathrm{GJ} \mathrm{ha}^{-1}$, EUE is drastically declining from $9 \mathrm{GJ} \mathrm{ha}^{-1}$ to $2 \mathrm{GJ} \mathrm{ha}^{-1}$ (Kukk et al., 2011). A positive energy balance (or efficiency) is achievable due to photosynthetic activity, which enables different crops to accumulate large amounts of energy in biomass, which are several times higher than energy expenses involved in cultivation technology. All the agrotechnological means used (crops, fertilizers, chemical, soil management) can be identified as supportive means to accumulate greater amount of energy in plants biomass (Agroenergetics and yield, 1990).

As has been mentioned before, the trials with both grasses were performed in the experimental site, which has a low soil acidity level $(\mathrm{pH} 4.25-4.85)$ and is characterized as unfavourable due to low profitability for many traditional agricultural crops. The data of our experiments are in line with those of other authors and suggest that both perennial grasses could be successfully grown under different types of agroclimatic conditions. It would be an adequate opportunity particularly for the farmers in the regions, which are classified as less favoured areas for agriculture. Growing of perennial grasses improves soil physical, chemical and biological features as well as the amount of organic matter (Strašil, 2012). Moreover, liming as an agrotechnical means could improve the above mentioned soil properties, though these aspects were not addressed in the article. However, although liming had a positive impact on biomass productivity in some cases, its application is inexpedient from energy point of view. Thus, although both grass species could be successfully cultivated as energy crops in Albeluvisol under different soil $\mathrm{pH}$ levels, from the energy point of view, reed canary grass is superior to cocksfoot. In order to ascertain grass sward longevity, biomass parameters as well as availability for different biofuel types, the investigations with cocksfoot and reed canary grass swards are being continued.

\section{Conclusions}

1. Averaged data of three experimental seasons indicated that the highest annual cocksfoot dry mass (DM) yield (7215 $\left.\mathrm{kg} \mathrm{ha}^{-1}\right)$, including $1^{\text {st }}$ and $2^{\text {nd }}$ cuts, was recorded in 2011. A significant cocksfoot sward DM yield increase was obtained by application of $6.0 \mathrm{t} \mathrm{ha}^{-1}$ lime material and $120 \mathrm{~kg} \mathrm{ha}^{-1} \mathrm{~N}$ rate.

2. The most productive reed canary grass sward was also obtained in 2011, when the average annual DM yield totalled $10833 \mathrm{~kg} \mathrm{ha}^{-1}$. The influence of liming was insignificant, although the application of $120 \mathrm{~kg} \mathrm{ha}^{-1} \mathrm{~N}$ rate caused a significant increase of reed canary grass DM yield.

3. The total energy consumption (direct and indirect inputs, machinery consumption and human labour input) for grass cultivation technology totalled 8.54-29.25 GJ ha-1 of which lime and mineral fertilizers accounted for a considerable share.

4. The annual amount of total energy accumulated in cocksfoot biomass constituted 59-165 GJ $\mathrm{ha}^{-1}$ and in reed canary grass $84-228 \mathrm{GJ} \mathrm{ha}^{-1}$, on average. The $120 \mathrm{~kg} \mathrm{ha}^{-1} \mathrm{~N}$ rate had a positive effect on energy use efficiency (energy output/input ratio).

\section{Acknowledgements}

The study was conducted in compliance with the long term program "Plant biopotential and quality for multifunctional practice".

Received 18112013

Accepted 31102014

\section{References}

Agroenergetics and yield. 1990 / compiled by A. Aleksynas. Vilnius, Lithuania, 42 p. (in Lithuanian)

Carlson I. T., Oram R. N., Surprenant J. 1996. Reed canarygrass and other Phalaris species. Moser L. E. (ed.). Cool-season forage grasses, p. 569-604

Grass forage production. 2001 / monograph, compiled by J. Sirvydis. Lithuanian Institute of Agricultural Engineering, 186 p. (in Lithuanian) 
Green M. B. 1987. Energy in pesticide manufacture, distribution and use. Helsel Z. R. (ed.). Energy in plant nutrition and pest control, p. 165-177

Heinsoo K., Hein K., Melts I., Holm B., Ivask M. 2011. Reed canary grass yield and fuel quality in Estonian farmers' fields. Biomass and Bioenergy, 35: 617-625 http://dx.doi.org/10.1016/j.biombioe.2010.10.022

Hulsbergen K. J., Feil B., Biermann S., Rathke G. W., Kalk W. D., Diepenbrock W. 2001. A method of energy balancing in crop production and its application in a long-term fertilizer trial. Agriculture, Ecosystems and Environment, 86: 303-321 http://dx.doi.org/10.1016/S0167-8809(00)00286-3

Jasinskas A. 2003. The energetic evaluation of vegetative plants fuel preparing technology. Žemès ūkio inžinerija, 35 (4): 70-81 (in Lithuanian)

Jasinskas A., Zaltauskas A., Kryzeviciene A. 2008. The investigation of growing and using of tall perennial grasses as energy crops. Biomass and Bioenergy, 32: 981-987 http://dx.doi.org/10.1016/j.biombioe.2008.01.025

Junquan Z., Michalk D. L., Yifei W., Kemp D. R., Guozhen D., Nicol H. 2007. Effect of phosphorus, potassium and lime application on pasture in acid soil in Yunnan Province, China. New Zealand Journal of Agricultural Research, 50 (4): 523-535 http://dx.doi.org/10.1080/00288230709510320

Kryževičienė A. 2006. Herbaceous plants as a renewable source of bioenergy. Ekologija, 2: 66-71 (in Lithuanian)

Kryževičienė A., Žaltauskas A., Jasinskas A. 2005. Cultivation and utilization of the perennial grasses as biofuel. Žemès ūkio mokslai, 1: 40-49 (in Lithuanian)

Kryževičienė A., Jasinskas A., Gulbinas A. 2008. Perennial grasses as a source of bioenergy in Lithuania. Agronomy Research, 6 (spec. iss.): 229-239

Kukk L., Roostalu H., Suuster E., Rossner H., Shanskiy M., Astover A. 2011. Reed canary grass biomass yield and energy use efficiency in Northern European pedoclimatic conditions. Biomass and Bioenergy, 35: 4407-4416 http://dx.doi.org/10.1016/j.biombioe.2011.08.018

Levesque M. P., Mathur S. P. 1983. Effect of liming on yield and nutrient concentration of reed canarygrass grown in two peat soils. Canadian Journal of Soil Science, 63: $469-478$ http://dx.doi.org/10.4141/cjss83-048

Lewandowski I., Jonathan M. O. Scurlock J. M. O., Lindvall E., Christoud M. 2003. The development and current status of perennial rhizomatous grasses as energy crops in the US and Europe. Biomass and Bioenergy, 25: 335-361 http://dx.doi.org/10.1016/S0961-9534(03)00030-8

Mažvila J. 2010. Acidity of Lithuanian soils $(\mathrm{pH})$ and their fluctuation. Management of agroecosystem components. Results of long-term agrochemical experiments: monograph / compiled by Tripolskaja et al. Lithuanian Research Centre for Agriculture and Forestry, p. 77-85 (in Lithuanian)

McKendry P. 2002. Energy production from biomass. Part I. Overview of biomass. Bioresource Technology, 83: 37-46 http://dx.doi.org/10.1016/S0960-8524(01)00118-3

Mills A., Moot D. J., Jamieson P. D. 2009. Quantifying the effect of nitrogen on productivity of cocksfoot (Dactylis glomerata L.) pastures. European Journal of Agronomy, 30: $63-69$

http://dx.doi.org/10.1016/j.eja.2008.07.008
Poozesh V., Castillon P., Cruz P., Bertoni G. 2010. Re-evaluation of the liming-fertilization interaction in grasslands on poor and acid soils. Grass and Forage Science, 65 (2): 260-272 http://dx.doi.org/10.1111/j.1365-2494.2010.00744.x

Saijonkari-Pahkala K. 2001. Non-wood plants as raw material for pulp and paper: academic dissertation. Agricultural and Food Science in Finland, 101 p.

Shahin S., Jafari A., Mobli H., Rafiee S., Karimi M. 2008. Effect of farm size on energy ratio for wheat production: a case study from Ardabil province in Iran. American Eurasian Journal of Agricultural and Environmental Science, 3 (4): 604-608

Strašil Z. 2012. Evaluation of reed canary grass (Phalaris arundinacea L.). Research in Agricultural Engineering, 58: $119-130$

Šateikis A. 2006. Potential of plant biomass cultivation and use for solid fuels and priority of research the present problems. Žemès ūkio inžinerija, 38 (3): 5-21 (in Lithuanian)

Tarakanovas P., Raudonius S. 2003. Statistic analysis of agronomical research data with computer programs ANOVA, STAT, SPLIT-PLOT from packet SELEKCIJA and IRRISTAT. Lithuanian University of Agriculture, $58 \mathrm{p}$. (in Lithuanian)

Tarakanovas P., Chomiak M. 2008. Evaluation of dry matter yield and its stability for cocksfoot varieties. ZemdirbysteAgriculture, 95 (1): 153-161 (in Lithuanian)

Tilvikienè V., Venslauskas K., Navickas K., Župerka V., Dabkevičius Z., Kadžiulienė Ž. 2012. The biomass and biogas productivity of perennial grasses. ZemdirbysteAgriculture, 99 (1): 17-22

Wrobel C., Coulman B. E., Smith D. L. 2009. The potential use of reed canarygrass (Phalaris arundinacea L.) as a biofuel crop. Acta Agriculturae Scandinavica, Section B: Soil and Plant Science, 59 (1): 1-18 http://dx.doi.org/10.1080/09064710801920230 
ISSN 1392-3196 / e-ISSN 2335-8947

Zemdirbyste-Agriculture, vol. 101, No. 4 (2014), p. 403-410

DOI 10.13080/z-a.2014.101.051

\title{
Paprastosios šunažolės bei nendrinio dryžučio produktyvumas balkšvažemyje ir auginimo technologijos energetinis ivertinimas
}

\author{
G. Šiaudinis, D. Karčauskienė, A. Šlepetienè
}

Lietuvos agrarinių ir miškų mokslų centro Vėžaičių filialas

\begin{abstract}
Santrauka
Tiriant dvi daugiametes miglinių šeimos žoles - paprastają šunažolę (Dactylis glomerata L.) ir nendrinį dryžuț (Phalaris arundinacea L.), siekta įvertinti kalkinimo ir tręšimo azotu įtaką jų biomasès produktyvumui ir atlikti energetinę auginimo technologijos analizę. Tyrimų vietos dirvožemis - rūgštus moreninis priemolis (Jlj6-b, pH 4,2-4,4). Tyrimai atlikti pagal dviejų veiksnių schemą: augalai kalkinti trimis normomis kalkių (nekalkinta, kalkinta 3,0 bei $6,0 \mathrm{t} \mathrm{ha}^{-1} \mathrm{CaCO}_{3}$ v. m.) ir tręšti trimis normomis azoto trąšų $\left(0,60\right.$ bei $\left.120 \mathrm{~kg} \mathrm{ha}^{-1} \mathrm{~N}\right)$.

Remiantis trejų metų tyrimų vidutiniais duomenimis, didžiausias tirtų žolių produktyvumas nustatytas $2011 \mathrm{~m}$., kai šunažolių sausos masès derlius siekė $7215 \mathrm{~kg} \mathrm{ha}^{-1}$, o dryžučių - $10833 \mathrm{~kg} \mathrm{ha}^{-1}$ (įskaitant pirmą ir antrą pjūtis). Kalkinès medžiagos 6,0 t ha $^{-1}$ panaudojimas turèjo teigiamos įtakos šunažolių sausos masės derliaus priedui, tačiau neturèjo esminès įtakos dryžučių sausos masès derliui. Abiejų žolių produktyvumui didžiausios įtakos turèjo azoto trąšos. Lyginant su kontroliniu variantu $\left(0 \mathrm{~kg} \mathrm{ha}^{-1} \mathrm{~N}\right)$, didžiausios normos $\left(120 \mathrm{~kg} \mathrm{ha}^{-1}\right)$ azoto trąšų panaudojimas šunažolių sausos masės derlių padidino $220 \%$, o nendrinių dryžučių - $243 \%$.

Atlikus auginimo technologijos energetini ivvertinimą nustatyta, kad bendrosios sąnaudos (tiesioginès ir netiesioginès sąnaudos, mašinų energoimlumas, žmonių darbas) siekia 8,54-26,02 $\mathrm{GJ} \mathrm{ha}^{-1}$. Didelè jų dalis tenka kalkinei medžiagai ir mineralinėms trąšoms - nuo 2,45 iki 19,39 $\mathrm{GJ}^{\text {ha-1 }}$. Per vienus metus šunažolių biomasėje susikaupe vidutiniškai 59-165 GJ ha ha $^{-1}$, dryžučių biomaseje - 84-228 GJ ha ${ }^{-1}$ GJ ha ${ }^{-1}$ energijos. Dèl to auginant dryžučius buvo pasiektas didžiausias energijos efektyvumas (energijos išeigos ir sąnaudų santykis), kuriam teigiamos įtakos turèjo $120 \mathrm{~kg} \mathrm{ha}^{-1}$ azoto trąšų panaudojimas.
\end{abstract}

Reikšminiai žodžiai: azotas, dryžučiai, energetinis auginimo technologijos įvertinimas, kalkinimas, šunažolès. 